\title{
Changing Classroom Practices through a One-to-One Laptop Program in Rural Argentina: Experiences of Schools in San Luis
}

\author{
Daniel Light \\ Center for Children and Technology, \\ Education Development Center, Inc.
}

\author{
Elizabeth Pierson \\ Center for Children and Technology, \\ Education Development Center, Inc.
}

\begin{abstract}
Since all learning is situated and embedded in a context, the research on laptops and classroom experience-much of which has been done in wealthy countries-may not reflect the experience of schools in less-developed countries. This paper examines successful technology integration, including a laptop program, in three Argentine schools. Many of the ICT-enriched practices we observed involved the integration of new digital tools into traditional Argentine pedagogical practices. We found that teachers were adapting old practices to work in the new technology-rich context in ways that provoked some fundamental changes in the learning environment. Five key impacts we observed were increased efficiency in classroom management; increased access to educational resources, resulting in more time on task; increased student ownership of the learning process; interactive resources that offered more frequent feedback to students; and more fluid communication among teachers, students, and parents.
\end{abstract}

\section{Introduction}

Over the last decade, one-to-one computing programs and laptop programs have been a popular approach to education reform in developing countries. One motivation behind these programs is the desire to use a single powerful resource to overcome the historical lack of educational tools and resources available in developing countries. The research on laptop programs in these countries often finds that such programs help bridge the digital divide and improve students' technical fluency, but the desired impact on academic achievement remains elusive [1-3]. A frequent problem identified in the research is that once the laptops are distributed to the children, they may seldom be used in the classrooms. The key challenges to their use appear to be inadequate teacher training, time constraints, and outdated teaching approaches. However, the research rarely delves more deeply into how laptops might be more completely integrated into daily classroom use $[2,4-8]$.
The technology tools provided to all students and teachers in a one-to-one program are arguably one of the most robust and multifaceted sets of resources that could be integrated into educational practice. Yet, when laptops arrive in a classroom, their use depends on how-or if-these new tools can be integrated into the resources, tools, and practices already in used. If teachers are unable to fit these new tools into their current practices, the devices risk being abandoned in a closet or left on a shelf to collect dust [9].

Understanding how technology fits into the complex realities of classrooms was a critical factor for change in developed nations, yet little is known about how laptop computers could be used in the classrooms of the developing world. Our study sought to shed more light on the issue of ICT integration by taking a close look at how laptops were used in the classrooms of schools with a successful laptop program - namely, All Kids Online (Todos los Chicos en la Red) in San Luis, Argentina.

\section{Program background}

EDC and Intel had been looking for a one-to-one program in a developing country that had achieved sufficient scale and that had external evaluation data regarding the program's success in improving students' academic performance. All Kids Online fit both criteria [10]. By September 2012, the program had distributed 64,064 laptops, and various evaluations and expert reviews had found an impact on academic performance [11-14].

All Kids Online is a one-to-one laptop program that provides all students with an Intel ${ }^{\circledR}$ Classmate $\mathrm{PC}$ - an affordable, durable, water-resistant netbook with full PC functionality, loaded with productivity software, education software, and wireless Internet, and designed especially for students to provide a collaborative, interactive learning experience for access both at home and at school. The program also provides the necessary technical support to maintain the machine. Along with a suite of other education enrichment programs, the provincial government is using a whole-child approach to making education gains throughout the province. 
The All Kids Online program is just one strand of a much larger provincial initiative to promote the long-term transformation of the province's economy and society. San Luis Digital, started in 2007, is an ambitious, province-wide digital inclusion initiative with its goals rooted in closing the digital divide through social and economic development [15]. The University of La Punta (ULP), a technical college on the outskirts of San Luis City, was established partly to carry out the government's education vision and technology plan. Currently ULP manages the various teacher training and educational enrichment programs as well as the data center and technical support network. In part, what enabled the successful development and implementation of All Kids Online, and all of the subsequent education programs, was the creation of an information superhighway. In 2008, connectivity was distributed for free to all villages with at least 20 inhabitants [15].

As an education reform program, the All Kids Online laptop initiative is part of a larger ecosystem of educational programs from the provincial government that impact the learning environment by providing educational opportunities and programs for students, resources for teachers to use with students, and training programs to provide teachers with new teaching strategies.

\section{Literature review}

The successful integration of ICT tools must be seen as a process. Research indicates that the integration of technology into instruction occurs over time and follows a pattern (see, for example, Sandholtz, Ringstaff, and Dwyer [16]). In their work focused principally on schools in developed countries, Zhao and Frank [17] suggest that the process of technology integration is an evolutionary one, and that teachers' beliefs, pedagogy, and technology skills slowly build on each other and coevolve as technology is introduced and assimilated into the school culture (p. 14). Initially, teachers incorporate new technologies into existing practices. But if the new technologies are powerful enough, teachers may begin to see changes, such as improvements in students' engagement, behavior, and learning, which will motivate them to experiment with newer uses of technology to teach in new ways.

Our exploration of the use of ICT tools in the classrooms of San Luis is grounded in a sociocultural theory of learning [18] that envisions learning as a social process where students develop and grow intellectually in interaction with other people, and where tools play a fundamental role in this process. Tools are embedded in all classroom practice, shaping everything that happens. ICT represents new sets of tools that replace, displace, or combine with previous tools and strategies. The Classmate PCs and other new tools may be used in new ways, or they may be spliced into old practices. Teachers may use tools in the ways envisioned by the program, or they may develop alternative strategies for using the tools. New tools can improve or hinder learning or have no effect-nonetheless, it is critical to understand how they are integrated into classroom practice.

Access to educational tools and resources can influence the possibilities for creating engaging and supportive learning environments for students. Providing good educational resources is a concern for all schools, but it is especially challenging for schools in developing countries, which frequently lack the educational tools and resources that schools in wealthier countries take for granted.

This lack of resources in the classroom manifests in many ways, including a lack of reference materials for students, either no textbooks at all or a few copies that students must share, no writing paper for students, no paper or no ink for the printer, no chalk - and the list can go on. The lack of such resources may mean that teachers cannot assign important learning activities, such as doing independent research, or writing a long essay or story; nor can they print student work to take home. Since educators in developing countries face these challenges every day, many teachers have developed teaching strategies and classroom management practices to work within these limitations.

An attraction of one-to-one laptop programs is the hope that providing each student and teacher with a laptop will not only make up for the historic lack of educational resources available to most Latin American schools, it will also move them into the future. However, if teachers are unable to incorporate these new tools into their current practices, the devices risk being abandoned in a closet or left on a shelf to collect dust [9].

\section{Research rationale and methodology}

With a grant from Intel ${ }^{\circledR}$, researchers from Education Development Center, Inc. (EDC), traveled to San Luis, Argentina, in August 2011 to conduct research in three schools that were part of the provincial education program Todos los Chicos en la Red (All Kids Online).

This study used an instrumental case study approach [19] with a very simple focus: to observe the classroom experience of students and teachers in schools where students are using laptops daily and to document the types of practices emerging around these tools. EDC coordinated with the leadership of All Kids Online to select exemplary schools that were using laptops daily. All Kids Online suggested three schools-two typical public schools that 
represent different aspects of the educational context of San Luis, and a third school, an innovative model school that had just opened.

The case studies were developed over two days of visits at the three schools. At each school we interviewed school leaders, classroom teachers and other educators, and the professional development coaches provided by All Kids Online. We observed classes and conducted informal interviews with students during the school day. Table 1 outlines the number of individuals interviewed at each school.

Table 1. School visits

\begin{tabular}{|c|c|c|c|c|c|c|}
\hline \multirow[b]{2}{*}{ School* } & \multicolumn{5}{|c|}{ Subjects Interviewed } & \multirow{2}{*}{ 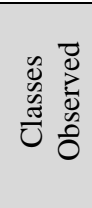 } \\
\hline & 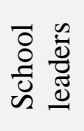 & $\begin{array}{l}\tilde{d} \\
\frac{\tilde{J}}{0} \\
\dot{0}\end{array}$ & $\begin{array}{l}\frac{\mathscr{\Xi}}{\tilde{\Xi}} \\
\stackrel{\Xi}{\oplus}\end{array}$ & 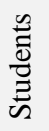 & 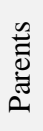 & \\
\hline $\begin{array}{l}\text { El } \\
\text { Manzanar }\end{array}$ & NA & 1 & 1 & 2 & & $\begin{array}{l}2 \text { full } \\
\text { days }\end{array}$ \\
\hline $\begin{array}{l}\text { Campo del } \\
\text { Cóndor }\end{array}$ & 1 & 1 & 5 & 5 & 1 & 6 \\
\hline $\begin{array}{l}\text { Escuela } \\
\text { Nicolás } \\
\text { Copérnico }\end{array}$ & 2 & NA & 3 & 5 & 1 & 10 \\
\hline Total & 3 & 2 & 9 & 12 & 2 & $\begin{array}{c}16+2 \\
\text { full } \\
\text { days }\end{array}$ \\
\hline
\end{tabular}

In addition to talking with school-based educators, we also interviewed the leadership of San Luis Digital, All Kids Online, ULP, and the various affiliated educational programs that support or coordinate with the laptop program.

\section{Findings}

This section presents findings from the three case study schools in the province of San Luis. Our observations and interview data are organized and synthesized under four main categories: school profiles, professional support, classroom practice, and impact on students. Our findings are analyzed in the Discussion and Conclusion sections.

\subsection{School profiles}

This section describes the three case study schools: the student population, the school's daily schedule, the building layout, the community demographics, and the technology infrastructure.
Table 2. Interviews with program staff

\begin{tabular}{|l|l|c|}
\hline Organization & \multicolumn{1}{|c|}{ Program } & Interview \\
\hline ULP & Rector & 1 \\
\hline \multirow{5}{*}{$\begin{array}{l}\text { All Kids } \\
\text { Online }\end{array}$} & Director & 1 \\
\cline { 2 - 3 } & $\begin{array}{l}\text { Alfabetización para el } \\
\text { Futuro (ICT Literacy } \\
\text { for the Future) }\end{array}$ & 1 \\
\hline \multirow{5}{*}{$\begin{array}{l}\text { San Luis } \\
\text { Digital }\end{array}$} & $\begin{array}{l}\text { Sero Balance } \\
\text { Program }\end{array}$ & 2 \\
\cline { 2 - 3 } & Contexts & 2 \\
\cline { 2 - 3 } & $\begin{array}{l}\text { San Luis Knowledge } \\
\text { Olympics }\end{array}$ & 2 \\
\cline { 2 - 3 } & $\begin{array}{l}\text { Grupo Recursos } \\
\text { Educativos Digitales }\end{array}$ & 3 \\
\cline { 2 - 3 } & $\begin{array}{l}\text { Taller de Artes y Juegos } \\
\text { Art and Games } \\
\text { Workshops) }\end{array}$ & 2 \\
\cline { 2 - 3 } & $\begin{array}{l}\text { Information Highway } \\
\text { Data Center }\end{array}$ & 1 \\
\cline { 2 - 3 } & $\begin{array}{l}\text { Technology Support } \\
\text { Team }\end{array}$ & 2 \\
\hline \multirow{2}{*}{ Total } & \multicolumn{1}{|c|}{$\mathbf{1 8}$} \\
\hline
\end{tabular}

5.1.1. El Manzanar-a one-teacher school. El Manzanar is a small school in a rural community about 30 minutes outside the capital of San Luis. There are 19 students, ranging from kindergarten to sixth grade and from ages 5 to 16 . The population in this community is fairly dispersed, and most students come a long way to get to school. Some walk a few miles to get there, but the school also has an arrangement with a local bus company to make a small detour from its normal route at the end of the school day to drop off students along the highway at locations a little nearer to their homes. The school day goes from 8:30 a.m. to 12:30 p.m., with time for recess. The children get breakfast and a snack at school.

The school has two adjoining classrooms. The inner classroom is for the younger children (kindergarten to third grade) and the other room is for the older students (fourth to sixth grade). There is an open doorway between the two rooms so that the teacher can easily see and hear all the students. The teacher, who also functions as the director, has a small office. There is also a small kitchen and eating area where students eat breakfast and have snack time. One woman serves as both cook and custodian, maintaining the kitchen and general public spaces.

Every student has a Classmate PC netbook and the teacher has a laptop. The upper grades' classroom also has an interactive whiteboard and a printer/scanner in the office. The school has a wireless connection, and all students have access to the provincial wireless network from their homes. El Manzanar uses the virtual learning environment created by ULP - the Sakai platform. There is no 
library at the school, but each classroom has a bookshelf with a few copies of the textbook distributed by the national government and a small selection of children's books. In addition to the laptop, each student brings a notebook or copybook (cuaderno escolar) to school every day. Because students seldom have a copy of the textbook for their personal use, Argentine students traditionally fill up their copybook throughout the year with important information dictated by the teacher or copied from a textbook; they also use it to take class notes and to do homework and other exercises [20].

5.1.2. Campo del Cóndor-a village school. Campo del Cóndor falls in the center of a tourist region in San Luis. The school has a unique socioeconomic mixture of poor, rural families and urban, middle-income families escaping the dense urban environment of Buenos Aires. Though these socioeconomic differences caused some tension in the school early on, the school director believes that the laptop program has equalized some of those differences by giving all students the same set of resources. In general, though, most of the students who attend the public school live in modest circumstances, with parents who move around a lot according to the seasons.

The school is well-respected in the area; the school director reports that many families bring their children to this school specifically. Campo del Cóndor goes up to sixth grade. In 2009, enrollment reached about 120 students, and the school was finally assigned a teacher for each grade. There are a total of six classroom teachers, one special education teacher, and the director. An art teacher and a physical education teacher also visit the school.

The Classmate PC netbooks were distributed to the children in October 2008, making Campo del Cóndor one of the first schools to take part in All Kids Online. However, some technological difficulties and connectivity issues meant that the teachers did not really begin to use the computers in the school until 2009. All Campo del Cóndor students are given netbooks when they are in first grade (or when they transfer to the school), and every teacher has a laptop from All Kids Online. Since 2010, every classroom has an interactive whiteboard that the school won through the Smart Schools program. The school also has wireless Internet connection and access to the learning platform. Additionally, the teachers report that all students live within range of a node of the provincial network, and they can access the network from anywhere in the village itself.

Campo del Cóndor has access to the virtual learning environment, the Sakai platform, but the teachers report that they are just now becoming familiar with it, so the students are not yet using it in many of the classes.

5.1.3. Escuela Nicolás Copérnico—an innovative, experimental school. The third school we visited is located in the city of San Luis. Escuela Nicolás Copérnico is decidedly different from the other schools in that it is one of the newly established model schools run by ULP under a special charter from the provincial government. These model schools are called Escuelas Digitales (Digital Schools), and they all have ubiquitous technology access with a focus on personalized learning. The 24 teachers, who work in all subject areas, were handpicked by the co-directors. The school had been open only three months when we visited. Nicolás Copérnico was built around three central tenets: personalized learning, technology, and the pursuit of excellence.

In total, the school has about 300 students in all three educational levels (30 pre-K and kindergarten, 120 primary, 150 secondary). Students are divided by age rather than grade, with about 20 students in each age-level "module." In their classes, students work through the material at their own pace; teachers typically have students working in groups, but each group may be studying a different topic. Teachers frequently monitor students' learning so they can adapt lessons to the students' education plans. The school is working toward designing and administering online tests as a means of more effectively monitoring students' progress.

The pedagogical model of Escuela Nicolás Copérnico was based on the model of the Escuela Fontán in Colombia, with a student-centered teaching model and mastery learning approach that allows each student to set his or her own pace. Nicolás Copérnico holds all students to high expectations for mastering the content, but there is no entrance exam to join the school-all students are welcome.

All students and teachers have computers, and every classroom has an interactive whiteboard. All the students, from kindergarten through high school, have Classmate PCs. The school has wireless Internet throughout and is using the Sakai platform from ULP. Since the school is in the city, all students have access to the wireless network through the provincial network throughout San Luis. At the time of the site visit, the school had only been open for three months, so the teachers were still developing their routines and getting used to the ICT infrastructure. More so than at the other schools, some Nicolás Copérnico teachers were still unsure of the reliability of the technology, and some of the classroom activities we observed reflected these concerns. For example, teachers had students 
copying from the whiteboard or the computer into their copybooks in case the computer crashed.

\subsection{Professional support}

All Kids Online has more than 300 pedagogical teacher coaches who work in all the schools as mentors to help their peers in a variety of ways. The coaches receive special training from ULP, which coordinates the coaching program. As could be seen from the schools we observed, the coaches develop a long-term relationship with the schools they are supporting.

Both El Manzanar and Campo del Cóndor had a coach from ULP, but at each school the coach played a very different role. At El Manzanar, the coach took a more pedagogical approach and was available to help the teacher look for new online resources, plan lessons, and integrate technology. The coach helped the teacher overcome her initial fear of the new technology, and the laptops have since become a vital and constant resource for her students. The pair of educators function as a team, working together to improve the educational environment at El Manzanar by planning lessons and selecting resources together.

Campo del Cóndor has both more teachers and more students than El Manzanar. The teachers at Campo del Cóndor are part of a strong learning community, and the school has a long and close relationship with ULP. When All Kids Online started, the school was already on its way to integrating more active-learning approaches; the technology simply provided new tools and access to new resources. Since the teacher corps at Campo del Cóndor already has a pedagogical vision, we observed that the coach had more of a technical and support role, helping teachers incorporate ICT into their vision. The coach focused on facilitating the interaction with the technicians to repair the laptops, aiding with facilitation of the various ULP educational programs, and helping teachers overcome technical difficulties on their computers and interactive whiteboards.

Since it is an experimental school, Nicolás Copérnico does not have an assigned coach, but the school's co-directors are deeply familiar with ULP's pedagogical paradigm and work closely to support their teachers in growing professionally to support that paradigm in the school. This school also has a unique professional development situation; the teachers eat together at the school and then spend the afternoon planning their lessons and working across modules to create curriculum and organize other special events. This collaboration across both age levels and subject areas helps teachers build a more cohesive teaching and learning community.

\subsection{Classroom practice}

Classroom practice and pedagogical approach varied by school. At El Manzanar, the one-teacher school, few students are at the same grade level, so the teacher has to constantly divide her time between students at different developmental stages, different levels of school readiness, and different grade levels. Students are expected to work on their own frequently while the teacher cycles on to other students. Throughout the school day, the teacher constantly moves between students and groups of students to work with one student while the others work independently or wait for her. During our classroom observations, almost every activity the teacher and students did involved the resources of All Kids Online (the laptops, whiteboard, Internet, or virtual learning platform). A positive side effect of the one-teacher schoolhouse dynamic is that older students help the younger ones quite a lot while the teacher gives her attention to an individual or a smaller group of students.

Unlike El Manzanar, each teacher at Campo del Cóndor has her own classroom and works with the same 20 students all day. Over two days, we observed six classes at this school. Most of the classes we observed were built around a whole-class activity led by the teacher, but technology still played a constant part of daily activities. All students have netbooks that they are expected to bring to class every day.

As a model school, the Nicolás Copérnico School has a unique pedagogical model that teachers have been trained to use and were beginning to implement in the classrooms. The core of the model is a focus on individualized learning pathways, where each student moves at his or her own pace through the material. In contrast to El Manzanar and Campo del Cóndor, where the whiteboard was the catalyst for many of the changes in classroom practice, at Nicolás Copérnico, the students' netbooks were at the center of most of the innovations. The teachers we spoke with wholeheartedly believe in this individualized model; one teacher stated that the more traditional model actually holds students back by forcing them to move at the same speed as their peers.

\subsection{Impact on students}

Across the schools, we observed that the consistent use of laptop and interactive whiteboard technologies coupled with access to the Sakai online learning platform had a number of positive impacts on students. The three main areas of impact were (1) improved academic achievement, (2) increased engagement, and (3) personal growth. 
Teachers and administrators at both El Manzanar and Campo del Cóndor agreed that since the integration of the laptops, their students' levels of academic achievement have improved. The laptops impact the ways that students engage with learning content by enabling them to get immediate feedback and allowing them to cover more material. In El Manzanar, the teacher was able to assign interactive resources that would give students immediate feedback on whether their response was correct. Students were then able to move more quickly through the material they understood and even do more work to reinforce their learning. The El Manzanar teacher noted that the students did not like to read from the few books she had available at the school, but now, with material available on the computer, they enjoy reading. The instructional coach observed that access to and use of the laptops have improved students' communication skills and that more students are passing their classes. At Campo del Cóndor, the instructional coach noted an increase in technical knowledge; students are now able to use PowerPoint, make videos, and solve technical problems on their own. One teacher spoke about increased writing output-for students who don't like to write, typing is better for them because they can move faster. A parent we spoke with shared a similar anecdote about her daughter reading and writing her own stories now that she could use a keyboard rather than a pencil and paper.

At Campo del Cóndor and Nicolas Copérnico, nearly everyone we spoke to agreed that the students are more motivated and enthusiastic about school since the introduction of the laptops. One parent even said that her child was also more motivated to do schoolwork at home, where she can play games, browse pictures, look up answers to questions, and use the education software that is included with the computer. At Nicolas Copérnico, despite the fact that students had more work and had to put in more effort at school, they universally preferred their learning environment to that of their previous schools. One student described it as "more fun," and another student said she likes having the computer because it is more interesting than just taking notes off the blackboard. The directors reported that students return to school on time after a vacation period, whereas before they were likely to disregard the set vacation dates and come back a number of days later.

The adults across schools noted ways in which the students are growing and expanding their horizons based on their access to the Internet through their laptops. The director at Campo del Cóndor mentioned that the computer acts as an economic equalizer for students. The Aula lal (One-to-One Classroom) software has a chat function as well as a discussion forum so that students can interact with their peers at their own schools and at other schools.
The laptops also afford great access to resources for students who come from the most rural areas. These children now have more access to music, news, and other information, helping to expand their knowledge of issues both locally and beyond.

Directors and teachers alike agreed that students' self-esteem has improved. Students who were quiet before are now more active and more outgoing. Students can see things they have published on the Internet; their work does not only live in the classroom, it is shown to a wider audience as well, which helps students see that their work is valued. High-level students can move through the material at their own pace and feel good about the progress they are making.

\section{Discussion}

In all three schools, we saw how the laptops and the ICT resources had become a daily part of learning in the classroom; pre-existing teaching-andlearning strategies were being modified and enriched by the new technology. Some older strategies were slowly being displaced, and new ones were emerging.

In these classrooms, the Classmate PCsembedded in an ecosystem of interactive whiteboards, a virtual learning platform, and universal wireless connectivity-were being used as frequently as typical Argentine students use their copybooks, and for many of the same purposes. In the absence of other resources, the copybook in Latin American schools is a combination homemade textbook, workbook, study guide, and notebook, as well as a portfolio of work so that parents and teachers can monitor each student's progress [2123]. The laptop was now taking the copybook's place as a vital part of teachers' and students' learning environment.

The educational tools provided by All Kids Online were also fundamentally changing the learning process, making the teacher's job easier, enabling their teaching to be more effective, and leading to substantial improvements in student learning. We noted changes in five major areas, which are described below.

\subsection{Increased efficiency in classroom management}

The laptops and interactive whiteboards greatly facilitated critical classroom logistics, such as distributing resources to students and putting up material on the whiteboard, allowing teachers to spend more time teaching. The ease of distributing resources using the virtual learning platform to place materials directly into each student's folder also 
allowed teachers to personalize resources to each student's level. In schools with a four-hour school day, time was a precious resource.

\subsection{Increased access to educational resources, creating more time on task}

Both teachers and students were using a wider variety of resources to meet their learning needs with the laptop and other ICT resources. The Internet offered access to a wide range of resources - from complex activities, such as interactive math problems, to moderately complex ones, such as videos and images, to simpler resources, such as more varied stories to interest young rural readers. But the technology also allowed teachers to make their own resources: Some teachers scanned reading material to share with students, and more technically proficient teachers created digital resources, such as interactive worksheets. The biggest change for students was that they each had their own copies of all the materials they were using in school, and they could take these resources anywhere with them. In schools with insufficient textbooks, libraries, and other educational resources, this can make a substantial impact.

\subsection{Increased student ownership of the learning process}

Having both full ownership of the laptop from All Kids Online and universal access to the Internet increased students' ability to have more autonomy and direct their own learning. With the laptop, they could more easily find their assignments and start working, and those students who were moving faster could do more activities or extra work. Students also were able to do work at home and to use the Internet to explore a topic. Shifting control of their own pacing and progress through the material to the students increased their autonomy and made it possible for them to push themselves harder.

\subsection{Interactive resources offer more frequent feedback to students}

This change is connected to the one above. Across a range of basic skills and abilities, such as math and spelling, the introduction of interactive digital resources was a way to give students immediate feedback, enabling them to try something, assess their work, and redo it on their own. We saw how activities as simple as an interactive worksheet helped learners practice and problem-solve their spelling. This enabled teachers to make better use of their time with students, and allowed students to study outside of school.

\subsection{More fluid communication between teachers, students, and parents}

The laptop and Internet connectivity also changed how students, teachers, and parents communicated in a couple of ways. Two of these schools did parent workshops about the laptops so that parents could learn how to review student work just as they did with the copybook. Some of the families had begun to use e-mail. All of the students were using a chat tool such as Skype or Messenger to be in touch with their friends, and most of them chatted with their teachers as well. Through chat, teachers were able to remind students about homework, and students were able to ask teachers questions.

\section{Conclusion}

There are many pending questions about one-toone programs in developing countries, given the varied success rates of many of these large-scale projects. In this project, we attempted to approach only one question-Why do many teachers not use the laptop resources?- - by looking closely at schools and classrooms where the tools are being used in context. What we found was very interesting, and suggests that laptop programs in developing countries may want to think carefully about how these new resources can intersect with a country's existing educational strategies and tools in ways that can not only begin to improve student outcomes, but also lay the groundwork for deeper reform.

All learning is situated and embedded in a context. Much of the research on classroom experience with laptops has been done in the resource-rich classrooms of industrialized countries; however, the learning experiences of teachers and students in these countries are, obviously, different from those of teachers and students in the classrooms of less wealthy countries. Our findings shed valuable light on how ICT tools were positively integrated into the under-resourced classrooms typical of many developing-country schools.

Our observations align with the perspective of Zhao and Frank [17] - that ICT integration occurs in phases as teachers assimilate new tools and new strategies into their daily practice. Although some of the teachers we visited were experimenting with innovative practices, such as project-based learning, in their daily practice teachers were not abandoning their old resources or teaching models, nor were they resisting ICT. Rather, they were adapting old practices to work in this new, technology-saturated context. Many ICT-enriched practices we observed involved a combination of new digital tools and 
traditional Argentine pedagogical practices. Infusing ICT into teachers' current practices caused some fundamental changes in those practices, making them potentially more effective.

This research was only an exploratory examination of what daily use of laptops looks like in a developing-country context. But many of these hybrid activities - older practices combined with new tools - hold the potential for positive impacts on student learning, since they align with known aspects of good practice: increasing time on task, allowing students more control over their work flow, giving students their own textbooks or reference materials, and providing more and varied resources and activities for students. We do not mean to argue that there is no need for deeper pedagogical reform, but rather that mixed approaches that transform current common practices may be a good place to start integrating ICT, improving education, and building for reform.

\section{Acknowledgments}

This research was funded by a grant from Intel ${ }^{\circledR}$.

\section{References}

[1] O. Valiente, 1-1 in Education: Current Practice, International Comparative Research Evidence and Policy Implications, OECD Publishing, Paris, 2010.

[2] R. Winthrop and M.S. Smith, A New Face of Education: Bringing Technology into the Classroom in the Developing World, Brookings Institution, Washington, DC, 2012.

[3] Zucker, A., and D. Light, "Laptop Programs for Students," Science, January 2, 2009, pp. 82-85.

[4] S. Akbaba-Altun, "Complexity of Integrating Computer Technologies into Education in Turkey," Journal of Educational Technology and Society, 2006, pp. 176-187.

[5] Comenius, "Informe Final-Enlaces Portátil: Abriendo Camino para un país digital," Centro para el Desarrollo de Innovaciones en Educación, Universidad de Santiago Chile, Santiago, 2008.

[6] Kraemer, K., J. Dedrick, and P. Sharma, "One Laptop Per Child: Vision Versus Reality," Communications of the ACM, 2009, pp. 66-73.

[7] D. Light and C. Rockman, Evaluation of the Jordan Education Initiative, Education Development Center, Inc., Washington, DC, 2008, p. 57.

[8] U. Vyasulu Reddi and V. Sinha, "India," in Metasurvey on the Use of Technologies in Education in Asia and the Pacific, G. Farrell and C. Wachholz, Eds., UNESCOBangkok, Bangkok, Thailand, 2003, pp. 245-252. [9] I. Jara Valdivia, "Las políticas de tecnología para escuelas en América Latina y el mundo: Visiones y lecciones," Comisión Económica para América Latina (CEPAL), Santiago, Chile, 2008.

[10] A. Bañuelos, "San Luis, a Digital State: How we support the work of teachers and students," paper presented at the International Conference on 1-to-1
Computing in Education, Vienna, Austria, February 22-24, 2010.

[11] A. Bañuelos, "San Luis: Tecnología y Educación," paper presented at Reinventar el Aula: Impacto Social y Educativo de la Incorporación de TICs en la Educación, Washington, DC, September 15, 2009.

[12] I. Dussel and L.A. Quevedo, "Educación y nuevas tecnologías: Los desafíos pedagógicos ante el mundo digital," paper presented at VI Foro Latinoamericano de Educación, Buenos Aires, Argentina, 2010.

[13] S. Finquelievich and A. Prince, El desarrollo de una provincia digital La Punta, Universidad de La Punta, San Luis, Argentina, 2010.

[14] Fundación CEPP, Evaluación del programa "Todos los chicos en la Red"-Informe de Resultados, Fundación CEPP, Buenos Aires, Argentina, 2008.

[15] S. Miranda and M.C. Odicino, Todos los Chicos en la Red: Iniciativa de la agenda digital de San Luis, Universidad de la Punta, San Luis, Argentina, 2009.

[16] J. Sandholtz, C. Ringstaff, and D.C. Dwyer, Teaching with technology: Creating student-centered classrooms, Teachers College Press, New York, 1997, pp. xx, 211. [17] Zhao, Y., and K.A. Frank, "Factors Affecting Technology Uses in Schools: An Ecological Perspective," American Educational Research Journal, 2003, pp. 807840.

[18] L.S. Vygotsky, Mind Society: The Development of Higher Psychological Processes, M. Cole, V. JohnSteiner, S. Scribner, and E. Souberman, Eds., Harvard University Press, Cambridge, MA, 1978.

[19] R. Stake, "A Problematic Heading," American Journal of Evaluation, Fall 2001, pp. 349-354.

[20] S. Gvirtz, S. Larripa, and Á. Oría, Prácticas discursivas pedagógicas, didácticas y escolares: algunas categorías para repensar la relación entre el saber y la escuela. Observatório Latinoamericano de Políticas Educacionáis, Rio de Janeiro, 2006.

[21] Almeida Costa e Santos, A., and M. Proença Rebello de Souza, "Cadernos escolares: Como e o que se registra no contexto escolar?" Psicologia Escolar e Educacional, 2005, pp. 291-302.

[22] A.-M. Chartier, "Os Cadernos Escolares: Organizar Os Saberes, Escrevendo-Os," Revista De Educacao Publica, 2007, pp. 13-33.

[23] M. A. Tenutto, “¿Es posible una aproximación de la Teoría con la práctica?" Contexto Educativo: Revista Digital de Educacion y Nuevas Tecnologias, Nueva Alejandria, Buenos Aires, Argentina, May 2000, vol. 7. 